\title{
Data report: alteration of basalts from Sites U1346 and U1349 at Shatsky Rise oceanic plateau, IODP Expedition 324'
}

\author{
Adélie Delacour $^{2}$ and Damien Guillaume ${ }^{2}$
}

\section{Chapter contents}

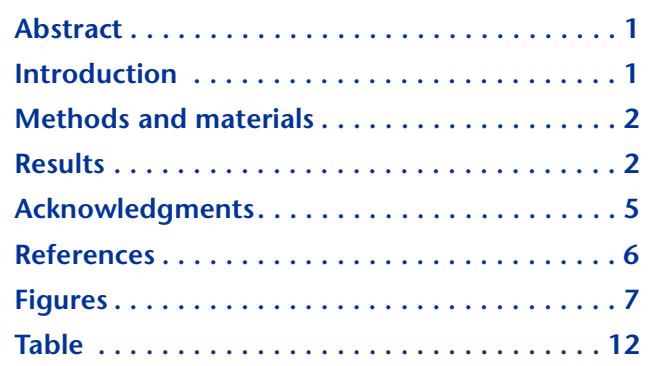

'Delacour, A., and Guillaume, D., 2013. Data report: alteration of basalts from Sites U1346 and U1349 at Shatsky Rise oceanic plateau, IODP Expedition 324. In Sager, W.W., Sano, T., Geldmacher, J., and the Expedition 324 Scientists, Proc. IODP, 324: Tokyo (Integrated Ocean Drilling Program Management International, Inc.). doi:10.2204/iodp.proc.324.203.2013 ${ }^{2}$ Géosciences Environnement Toulouse, UMR 5563, Observatoire Midi-Pyrénées et Université Paul Sabatier Toulouse III, 14 avenue Edouard Belin, 31400 Toulouse, France. Correspondence author: adelie.delacour@univ-st-etienne.fr

\section{Abstract}

This paper presents alteration mineralogy of basalts from Sites U1346 and U1349 drilled during Integrated Ocean Drilling Program (IODP) Expedition 324 on Shatsky Rise oceanic plateau. These two sites are the more altered sites among the four basaltic sites drilled on the plateau and show the greatest variability in terms of alteration. X-ray diffraction (XRD) analyses were processed on nonoriented bulk rock powders and on oriented sections made after decarbonation of the $<2 \mu \mathrm{m}$ fraction of basalts, sampled at regular intervals from Holes U1346A and U1349A. These XRD analyses allow us to determine the nature and composition of clay minerals that predominantly replace primary mineralogy of the basalts and to evaluate the spatial variations in alteration conditions: lateral variations within the plateau and vertical variations within a single site. Alteration types differ between the two holes and include green alteration, brown alteration, and dark gray alteration in Hole U1346A, whereas Hole U1349A is characterized by red-brown alteration, a transition zone, and green alteration that differs significantly from that in Hole U1346A. Secondary mineral assemblages include smectites, calcite, kaolinite, illite, chlorite, zeolites, sulfides, Fe oxides (i.e., hematite), and Fe oxyhydroxides. These parageneses attest that basaltic rocks from the two sites were affected by low- to moderatetemperature alteration. Alteration at Shatsky Rise oceanic plateau is similar, although some differences occur, to that reported at oceanic plateaus (e.g., Ontong Java) and oceanic crust drilled during the Deep Sea Drilling Program and Ocean Drilling Program.

\section{Introduction}

Basaltic lavas of Shatsky Rise oceanic plateau, recovered during Integrated Ocean Drilling Program (IODP) Expedition 324, erupted during the Late Jurassic and Early Cretaceous ( 145 Ma; Mahoney et al., 2005) close to the triple junction of the PacificFarallon-Izanagui lithospheric plates. Since their emplacement on the ocean floor, the basaltic rocks have undergone fluid-rock interactions, whose conditions vary laterally from one site to another and vertically within a single site. Actually, the two Sites U1347 and U1350, located at the flanks of Tamu and Ori Massifs, respectively, are only slightly altered, whereas Sites U1346 and U1349, located on the summits of Shirshov and Ori Massifs, re- 
spectively, show the highest degrees of alteration with significant variations in alteration types with depth (see the "Expedition 324 summary" chapter [Expedition 324 Scientists, 2010a]). In order to precisely characterize types and conditions (temperature, redox, and water-rock ratios) of alteration of the two most altered sites, secondary mineralogy and especially the nature and characteristics of clay minerals were specifically identified by X-ray diffraction (XRD) on nonoriented bulk rock powder and on oriented sections of the decarbonated $<2 \mu \mathrm{m}$ fractions. These data complete preliminary secondary mineral characterizations made onboard by the Expedition 324 Scientific Party (Expedition 324 Scientists, 2010a).

\section{Methods and materials}

Preliminary results of IODP Expedition 324 (Expedition 324 Scientists, 2010a) reported that primary minerals of Shatsky Rise basalts at Sites U1346 and U1349 (clinopyroxene + plagioclase \pm olivine + Fe-Ti oxides) were altered and mainly replaced by clays associated with abundant calcite and minor zeolites. Mineral identification was based on optical microscopy on thin sections and XRD analyses of bulk rock powder. However, precise characterization of clay minerals onboard was complex, and their names were essentially based on their color (e.g., brown clays, green clays, etc.).

The objectives of our study were thus to identify precisely the nature of clay minerals and their characteristics for a selection of samples collected at Sites U1346 and U1349. A total of 20 samples, 8 samples from Site U1346 and 12 samples from Site U1349, chosen at regular intervals within each hole and as being representative in terms of alteration, were analyzed by XRD (Table T1) (Guillaume et al., 2004; Köster, 1995). After reducing basalt samples to a finegrained powder with a Fritsch Pulverisette equipped with an agate mill at Laboratoire Géosciences Environnement Toulouse (France), a two-step procedure was applied on all selected samples to identify clay minerals. First, XRD patterns of nonoriented bulk rock powders were obtained with a CPS 120 diffractometer $(\mathrm{CoK} \alpha$ radiation at $0.178897 \mathrm{~nm}$, operated at $40 \mathrm{kV}$ and $25 \mathrm{~mA}$; Laboratoire Géosciences Environnement Toulouse). Each XRD pattern was acquired on 1024 channels over $110^{\circ} 2 \theta$ and with a counting time of $15 \mathrm{~min}$. Based on these patterns, the presence of clay minerals was highlighted by a broad peak at $14-15 \AA$ (i.e., $6.6^{\circ}-8.2^{\circ} 2 \theta$; Fig. F1). However, because of high concentrations of carbonate in the samples (Delacour et al., 2012), peaks of clay minerals appear small on XRD patterns and are consequently difficult to identify precisely. Therefore, in a second step, decarbonation of the samples was applied at pH 5 (acetic acid-sodium acetate in solution to prevent alteration of clay particles), and the finest fraction $(<2 \mu \mathrm{m})$ of each sample was separated and prepared as oriented sections. These sections were then analyzed with an INEL G3000 diffractometer $(\mathrm{CuK \alpha}$ radiation at $0.15418 \mathrm{~nm}$, operated at $30 \mathrm{kV}$ and $40 \mathrm{~mA}$ with a step interval of $0.032^{\circ} 2 \theta$ and counting times of $3 \mathrm{~s}$; Laboratoire Géosciences Environnement Toulouse) in the region of short angles to identify the clay minerals under airdried condition (AD), after saturation with ethylene glycol (EG), and after heating at $550^{\circ} \mathrm{C}(\mathrm{H})$. The nature of the clay minerals was determined by the position of the (001) peak (Fig. F2). Chlorite is characterized by a peak at $14 \AA$ on the AD, EG, and H pattern. Smectite is characterized by a peak at $15 \AA$ on the $\mathrm{AD}$ pattern, which shifts to $17 \AA$ on the EG pattern and to $10 \AA$ on the $\mathrm{H}$ pattern. Kaolinite is characterized by a peak at $7 \AA$ on the AD and EG patterns, whereas no peak is observed on the $\mathrm{H}$ pattern because the mineral is destroyed by heating. A peak attributed to illite at $10 \AA$ is present on the AD, EG, and $\mathrm{H}$ pattern. The nature of smectite is determined using the relative position of the (060) peak on XRD patterns of the nonoriented bulk rock powders (Figs. F1, F3).

\section{Results}

Whereas the aim of this paper is to provide new mineralogical data concerning alteration of basaltic oceanic plateau, it also reports certain preliminary data collected during Expedition 324 on alteration types at each site. For a more detailed description of alteration at each site, see the "Expedition 324 summary" chapter and the "Site U1346" and "Site U1349" chapters in this volume (Expedition 324 Scientists, 2010a, 2010b, 2010c).

\section{Alteration at Site U1346}

Preliminary investigations of basalts at Site U1346 during Expedition 324 reported three main types of alteration: (1) green alteration, (2) dark gray alteration, and (3) brown alteration (see the "Site U1346" chapter [Expedition 324 Scientists, 2010b]), suggesting either variations in the compositions of circulating fluid and/or in conditions of fluid-rock interaction.

\section{Green alteration}

Green alteration affected only the uppermost two basaltic sections in Hole U1346A (from Section 324U1346A-4R-1 through 4R-2, at 120.0-120.8 meters 
below seafloor [mbsf]), which were interpreted as basement contact by Expedition 324 Scientists (Expedition 324 Scientists, 2010b). In these two sections, fluid-rock interaction was extensive, with an alteration degree of $80 \%-95 \%$, and preliminary investigations reported replacement of primary mineralogy by abundant clays, especially smectites, and calcite. The occurrence of calcite is confirmed by our XRD analyses on bulk rock powder (Fig. F4); however, these spectra, together with those of oriented sections, indicate the lack of smectites but the likely occurrence of celadonite with peaks at 10 and $1.517 \AA$ (Fig. F4). In addition, a peak at $9.0 \AA$ attests to the occurrence of zeolite minerals, likely belonging to the heulandite series. These zeolites form euhedral crystals growing on the rim of vesicles and are associated with ball-shaped sulfides and calcite that later filled the vesicles.

\section{Dark gray alteration}

Dark gray alteration is the most common alteration affecting the basalts in Hole U1346A (Expedition 324 Scientists, 2010b), and this alteration color is similar to the normal color of basalts. Replacement of primary minerals is low to moderately high (30\%70\%), and Expedition 324 Scientists reported that clays, the main phases of alteration, were difficult to determine precisely. Our XRD analyses on bulk rock and oriented sections reveal that smectites are predominantly hectorite/stevensite (i.e., Mg-smectites) at the top of the hole (e.g., Sample 324-U1346A-6R$2,5-10 \mathrm{~cm}$ [140.4 mbsf]), whereas the bottom of the hole is characterized by the occurrence of saponite/ hectorite ( \pm stevensite) and montmorillonite (i.e., Mg- and Al-smectites; Sample 324-U1346A-12R-1, 17.5-21.5 cm [168.0 mbsf]) (Table T1; Figs. F1A, F2A, F3A). Calcite is abundant in this alteration type, replacing primary minerals (olivine and pyroxene) and groundmass (Expedition 324 Scientists, 2010b).

\section{Brown alteration}

Brown alteration is observed in several intervals in Hole U1346A (e.g., Sample 324-U1346A-10R-1, 28$31 \mathrm{~cm}$ [159 mbsf]) (Table T1) and is superposed to the dark gray alteration (Expedition 324 Scientists, $2010 \mathrm{~b})$. Basalts affected by this type of alteration are moderately altered (30\%-60\%), and Expedition 324 Scientists determined that secondary mineralogy is predominantly brown clays. Our XRD analyses on bulk rock and oriented sections allowed us to more precisely identify these brown clays as hectorite \pm saponite \pm stevensite (i.e., Mg-smectites) associated with kaolinite as indicated by a peak at $7 \AA$ (Table T1). An important calcite peak is also present on the bulk rock XRD spectra, indicating that this phase is also a predominant secondary phase in the basalts, mainly as replacement of primary minerals and groundmass.

\section{Alteration at Site U1349}

Basaltic rocks at Site U1349 were affected by extensive fluid-rock interactions with variations in temperature, fluid fluxes, and redox conditions with depth as indicated by the change in secondary mineral assemblages with depth (see the "Site U1349" chapter [Expedition 324 Scientists, 2010c]). Three types of alteration were described by Expedition 324 Scientists, all being characterized by a predominant replacement of primary minerals by clays associated to various proportions of calcite: (1) red-brown alteration, (2) a transition zone between red-brown and green alterations, and (3) green alteration.

\section{Red-brown alteration}

Red-brown alteration moderately to extensively (50\%-100\%) affected basaltic rocks from the upper part of Hole U1349A from Section 324-U1349A-7R-2 through 12R-2 at 204.7 mbsf. The lower limit of this alteration zone was initially defined during Expedition 324 at the bottom of Section 12R-3, but a detailed examination of basaltic rocks and their mineralogy reveals that Section 12R-3 belongs to the transition zone between red-brown and green alteration. The main alteration phases identified by Expedition 324 Scientists and characterizing the redbrown alteration are iddingsite and calcite, which replace extensively olivine phenocrysts (Expedition 324 Scientists, 2010c). Iddingsite is defined as a pseudomorph of olivine composed by a mixture of clay minerals, Fe oxides (principally hematite), and ferrihydrides (a hydrous ferric oxyhydroxide). Expedition 324 Scientists reported that, based on XRD data, clay minerals forming iddingsite are mainly saponite and montmorillonite. The occurrence of montmorillonite is confirmed by XRD data on bulk rock and oriented sections, which also allow the determination of nontronite (a Fe-smectite) (Table T1). However, saponite was not clearly identified on our XRD spectra. It is noteworthy to mention that no smectite or clay mineral could be identified on XRD spectra of bulk rock powder and oriented sections of three basalt samples (324-U1349A-7R-3, 100-104 cm [168.0 mbsf], 10R-3, 90-95 cm [186.8 mbsf], and 12R-2 39$43 \mathrm{~cm}$ [204.4 mbsf]) (Table T1), whereas iddingsite was identified petrographically in thin sections. The only secondary mineral phase that could be identified on these XRD spectra was calcite (Fig. F5). Plagioclase microliths are also significantly altered, and alteration to brown clays and/or a K-rich phase (i.e., sanidine) was reported (Expedition 324 Scientists, 
2010c). Our XRD analyses did not allow identifying the presence of sanidine in the rocks, but illite, a Krich clay, was identified and most likely replaces plagioclase microliths. Occurrence of illite is consistent with the high bulk rock $\mathrm{K}$ contents measured in these basalts affected by red-brown alteration.

\section{Transition zone}

The transition zone defines the alteration type that affected basaltic rocks of Hole U1349A between the red-brown alteration above and the green alteration below (from Section 324-U1349A-12R-3 through 14R-3; $225.4 \mathrm{mbsf})$. Basaltic rocks in this zone are moderately to strongly (50\%-100\%) altered, and secondary minerals replacing clinopyroxene and plagioclase were mainly identified as clays by Expedition 324 Scientists, whereas iddingsite, saponite, and calcite were determined as secondary minerals replacing olivine phenocrysts (Expedition 324 Scientists, 2010c). Our XRD analyses on bulk rock powder and oriented sections indicate that saponite, hectorite, and/or stevensite are present as secondary minerals in all samples and allow determining occurrences of montmorillonite or nontronite, depending on the basalt samples (Table T1; Figs. F1B, F2B, F3B). These smectites likely replace primary Fe-Mg silicates, olivine, and clinopyroxene, which shows a higher degree of alteration in this transition zone than in the red-brown alteration above (Expedition 324 Scientists, 2010a). Two other clay minerals were identified as secondary minerals: kaolinite, present in all samples, and illite, occurring only in basalt samples at the bottom of the transition zone (e.g., Sample 324U1349A-14R-3, 5-9 cm; 224.0 mbsf) (Table T1; Figs. F1B, F2B). In addition, two other minerals, chlorite and calcite, complete the secondary mineral assemblages in almost all basaltic samples of the transition zone. Finally, Expedition 324 Scientists reported the occurrence of zeolites in this transition zone as replacement of groundmass glass or as filling veins (Expedition 324 Scientists, 2010c). A peak at $6.5 \AA ̊$ on bulk rock XRD patterns confirms that zeolites, likely natrolite or mesolite, are present as secondary minerals in basaltic rocks (Fig. F1B). However, their occurrences are not only restricted to the transition zone, as the peak is observable on XRD spectra of all basalt samples analyzed in Hole U1349A.

\section{Green alteration}

Green alteration is only present at the bottom of Hole U1349A and led to high to complete (70\%$100 \%)$ replacement of primary mineralogy of basaltic breccias to green clays. Expedition 324 Scientists reported replacement of clinopyroxene and plagioclase by brown clays, whereas olivines are replaced by saponite and calcite (Expedition 324 Scientists, 2010c). Our XRD analyses on bulk rock and oriented sections confirm the occurrences of saponite and hectorite in all samples, which are associated with montmorillonite at the bottom of the hole (e.g., Sample 324-U1349A-15R-6, 18-24 cm; $238.1 \mathrm{mbsf}$ ) (Table T1). Similar to the transition zone, kaolinite and chlorite \pm calcite complete the secondary mineral assemblages. Basaltic breccias are cemented by calcite and green clays, saponite, and nontronite (Expedition 324 Scientists, 2010a).

\section{Summary and discussion on alteration at Shatsky Rise}

Basaltic rocks in Holes U1346A and U1349A have undergone low- to moderate-temperature alteration with moderate to complete replacement of primary mineralogy (pyroxene, plagioclase, olivine, and Fe-Ti oxides) and glassy mesostasis. Clay minerals together with calcite are the most abundant secondary minerals. Chlorite, zeolites, sulfides, Fe oxides, and Fe oxyhydroxides are less abundant. XRD analyses on nonoriented bulk rock powders and on oriented sections allow us to precisely identify the nature of these clay minerals (Table T1). Various Mg-, Al-, and Fe-smectites, including saponite, hectorite, stevensite, montmorillonite, and nontronite, were identified in almost all basalt samples of the two holes. In addition, celadonite, kaolinite, illite, and smectite/chlorite mixed layers were also determined in basalts (Table T1). We compare the clay minerals identified in the basaltic rocks of Holes U1346A and U1349A to other well-studied portions of oceanic crust and other oceanic plateaus (Alt and Honnorez, 1984; Alt, 1995, 1999; Honnorez, 2003; Bannerjee and Honnorez, 2004).

Alteration types affecting Shatsky Rise basalts at the summit of Shirshov and Ori Massifs are distinguished by typical secondary mineral assemblages, which reflect variable conditions of fluid-rock interactions. In the upper part of Hole U1346A, green alteration forms alteration halos, which are characterized by celadonite and zeolite of the heulandite series. Heulandite was reported in altered basalts of Iceland as a result of low-temperature $\left(<100^{\circ} \mathrm{C}\right)$ fluid circulation (Kristmannsdottir, 1979). Celadonite is commonly described in vesicles and as main secondary phyllosilicates in black halos and is interpreted to result from initial alteration of young basaltic rocks (Laverne, 1987; Alt, 1999). However, black and dusky green halos composed of celadonite and Fe oxyhydroxides were also reported in $120 \mathrm{~m}$.y. old basalts of Ontong Java Plateau (Bannerjee and Honnorez, 2004). Secondary minerals of the green alteration at the top of Hole U1346A may thus suggest 
interaction of the basalts with low-temperature $\left(<60^{\circ} \mathrm{C}\right)$ seawater-derived fluids in the 1 or 2 m.y. after their emplacement (Böhlke et al., 1980; Honnorez, 1981; Laverne, 1987). Downhole, alteration type changes to dark gray alteration with various intervals of brown alteration. The dark gray alteration is mainly composed of Mg-smectites (saponite, hectorite, and stevensite) \pm Al-smectites (montmorillonite), and variable amounts of calcite. This mineral assemblage was also reported as an alteration product of basalts from Ontong Java Plateau (Bannerjee and Honnorez, 2004). Saponite is commonly described as a phyllosilicate resulting from long-term, low-temperature $\left(10^{\circ}-50^{\circ} \mathrm{C}\right)$ alteration (Alt, 1999). Brown alteration is superimposed on dark gray alteration and comprises significant intervals (up to $2.7 \mathrm{~m}$ long) of altered basalts characterized by hectorite \pm saponite \pm stevensite, kaolinite, and calcite as secondary minerals (Table T1). Kaolinite has never been described as an alteration product of oceanic basaltic rocks and is more commonly reported as resulting from weathering of feldspar or in sediment-hosted hydrothermal systems. No evidence of sediment in veins or vesicles was observed or reported in basalts affected by the brown alteration, suggesting that kaolinite may likely result from alteration of feldspar.

Similar to basalts in Hole U1346A, basalts in Hole U1349A are composed of various mineral assemblages, which define three types of alteration and suggest variable conditions of fluid-rock interactions. Red-brown alteration, affecting the basalts at the top of the hole, is characterized by an assemblage composed of iddingsite (Fe-smectites and hematite), illite, and calcite. Iddingsite, completely replacing olivine, suggests extensive interaction with fluids under low-temperature and oxidizing conditions. Iddingsite is commonly described as an alteration product of olivine in extrusive or subvolcanic rocks, suggesting that alteration of the upper part of Hole U1349A may have been subaerial (Expedition 324 Scientists, 2010a). The Shatsky Rise oceanic plateau is the only site of the ocean floor where iddingsite has been reported. Illite, a K-rich clay, has likewise never been described as an alteration product of oceanic basalts, illite being rather reported as a secondary mineral in more felsic rocks affected by hydrothermal circulation (Liou et al., 1985). As felsic rocks were not recovered at Shatsky Rise, occurrence of illite may be related to

1. Alteration of feldspar by K-rich seawater-derived fluid,

2. Contamination by overlying sedimentary rocks, or

3. Low-grade metamorphic processes affecting previously formed smectites.
Downhole, the secondary mineralogy changes drastically in the transition zone, with predominance of smectites (saponite, hectorite, stevensite, montmorillonite, and nontronite) associated with kaolinite, chlorite, calcite, and variable amounts of illite. Presence of smectite/chlorite mixed layers is supposed as indicated by XRD data (Fig. F2B) and was previously described as an alteration product of the volcanic section of Deep Sea Drilling Project Hole 504B (Alt et al., 1986). Occurrence of chlorite and/or smectite/ chlorite mixed layers suggests a higher temperature $\left(>100^{\circ} \mathrm{C}\right)$ of fluid-rock interaction under more reducing conditions and restricted fluid circulation (Alt, 1999). At the bottom of the hole, green alteration affecting the basalts is characterized by a secondary mineral assemblage composed of smectites (saponite, hectorite, and montmorillonite), kaolinite, and chlorite with variable amounts of calcite. Similar to the alteration assemblage of the transition zone, this secondary mineral assemblage attests to higher temperature conditions of alteration. Kaolinite in the transition and green alteration zones may be related, as in the brown alteration of Hole U1346A, to alteration of feldspar. Nevertheless, green alteration affects mainly basaltic breccias, which are cemented by clays and calcite, suggesting that sediment may also compose the cement between basaltic clasts, therefore explaining the occurrence of kaolinite in these samples.

It is worth pointing out significant abundances in carbonates and zeolites in basalts throughout the two holes, involving extensive circulation of alkaline fluids since emplacement of the plateau at Early Cretaceous times.

In conclusion, the various alteration types described at Shatsky Rise indicate that fluids of variable compositions circulated within the oceanic plateau and that fluid-rock interactions occurred under various temperature and redox conditions, depending on the structural levels of the basaltic lava flows.

\section{Acknowledgments}

We thank the captain, crew, and technical staff onboard the R/V JOIDES Resolution for their considerable and irreplaceable work to make Expedition 324 successful. This research used samples and data provided by Integrated Ocean Drilling Program (IODP). Participation of A. Delacour during Expedition 324 was funded by IODP France. We are grateful to Michel Thibaut and Chantal Aineto for their valuable help in preparing and processing samples for XRD analyses. We also would like to thank Jeff Alt for reviewing this data report. Funding for this research was provided by a French INSU-CNRS grant. 


\section{References}

Alt, J.C., 1995. Subseafloor processes in mid-ocean ridge hydrothermal systems. In Humphris, S.E., Zierenberg, R., Mullineaux, L., and Thomson, R. (Eds.), Seafloor Hydrothermal Systems: Physical, Chemical, Biological, and Geological Interactions. Geophys. Monogr., 91:85-114. doi:10.1029/GM091p0085

Alt, J.C., 1999. Very low grade hydrothermal metamorphism of basic igneous rocks. In Frey, M., and Robinson, D. (Eds.), Very Low Grade Metamorphism: Cambridge (Blackwell), 169-201.

Alt, J.C., and Honnorez, J., 1984. Alteration of the upper oceanic crust, DSDP Site 417: mineralogy and chemistry. Contrib. Mineral. Petrol., 87(2):149-169. doi:10.1007/BF00376221

Alt, J.C., Honnorez, J., Laverne, C., and Emmermann, R., 1986. Hydrothermal alteration of a $1 \mathrm{~km}$ section through the upper oceanic crust, Deep Sea Drilling Project Hole 504B: mineralogy, chemistry, and evolution of seawater-basalt interactions. J. Geophys. Res.: Solid Earth, 91(B10):10309-10335. doi:10.1029/JB091iB10p10309

Banerjee, N.R., and Honnorez, J., 2004. Data report: lowtemperature alteration of upper oceanic crust from the Ontong Java Plateau, Leg 192: alteration and vein logs. In Fitton, J.G., Mahoney, J.J., Wallace, P.J., and Saunders, A.D. (Eds.), Proc. ODP, Sci. Results, 192: College Station, TX (Ocean Drilling Program), 1-8. doi:10.2973/ odp.proc.sr.192.103.2004

Böhkle, J.K., Honnorez, J., and Honnorez-Guerstein, B.M., 1980. Alteration of basalts from Site 396B, DSDP: petrographic and mineralogical studies. Contrib. Mineral. Petrol., 73(4):341-364. doi:10.1007/BF00376628

Delacour, A., Andréani, M., and Guillaume, D., 2012. Carbonate precipitation in Shatsky Rise oceanic plateau and implications on carbon cycle [IODP-France Scientific Meeting, 10-11 April 2012, Paris, France].

Expedition 324 Scientists, 2010a. Expedition 324 summary. In Sager, W.W., Sano, T., Geldmacher, J., and the Expedition 324 Scientists, Proc. IODP, 324: Tokyo (Integrated Ocean Drilling Program Management International, Inc.). doi:10.2204/iodp.proc.324.101.2010

Expedition 324 Scientists, 2010b. Site U1346. In Sager, W.W., Sano, T., Geldmacher, J., and the Expedition 324 Scientists, Proc. IODP, 324: Tokyo (Integrated Ocean Drilling Program Management International, Inc.). doi:10.2204/iodp.proc.324.103.2010
Expedition 324 Scientists, 2010c. Site U1349. In Sager, W.W., Sano, T., Geldmacher, J., and the Expedition 324 Scientists, Proc. IODP, 324: Tokyo (Integrated Ocean Drilling Program Management International, Inc.). doi:10.2204/iodp.proc.324.106.2010

Guillaume, D., Neaman, A., Cathelineau, M., Mosser-Ruck, R., Peiffert, C., Abdelmoula, M., Dubessy, J., Villiéras, F., and Michau, N., 2004. Experimental study of the transformation of smectite at 80 and $300^{\circ} \mathrm{C}$ in the presence of Fe oxides. Clay Miner., 39(1):17-34. doi:10.1180/ 000985543910117

Honnorez, J., 1981. The aging of the oceanic crust at low temperature. In Emiliani, C. (Ed.), The Sea (Vol. 7): The Oceanic Lithosphere: New York (Wiley), 525-587.

Honnorez, J., 2003. Hydrothermal alteration vs. oceanfloor metamorphism. A comparison between two case histories: the TAG hydrothermal mound (Mid-Atlantic Ridge) vs. DSDP/ODP Hole 504B (equatorial East Pacific). C. R. Geosci., 335(10-11):781-824. doi:10.1016/j.crte.2003.08.009

Köster, H.M., 1995. Die röntgenographische Identifizierung der silikatischen Tonminerale und beigemengter Akzessorien in Texturpräparaten. Z. Geol. Wiss., 23:287300

Kristmannsdottir, H., 1979. Alteration of basaltic rocks by hydrothermal-activity at $100-300^{\circ} \mathrm{C}$. Dev. Sedimentol., 27:359-367. doi:10.1016/S0070-4571(08)70732-5

Laverne, C., 1987. Les altérations des basaltes en domaine océanique: minéralogie, pétrologie et géochimie d'un système hydrothermal: le puits 504B, Pacifique oriental [Thèse]. Univ. Aix-Marseille III, Aix-en-Provence.

Liou, J.G., Seki, Y., Guillemette, R.N., and Sakai, H., 1985. Compositions and parageneses of secondary minerals in the Onikobe geothermal system, Japan. Chem. Geol., 49(1-3):1-20. doi:10.1016/0009-2541(85)90143-3

Mahoney, J.J., Duncan, R.A., Tejada, M.L.G., Sager, W.W., and Bralower, T.J., 2005. Jurassic-Cretaceous boundary age and mid-ocean-ridge-type mantle source for Shatsky Rise. Geology, 33(3):185-188. doi:10.1130/ G21378.1

Initial receipt: 7 September 2012

Accepted: 28 February 2013

Publication: 3 May 2013

MS 324-203 
Figure F1. X-ray diffraction patterns obtained on nonoriented bulk rock powder of two basaltic samples, Sites U1346 and U1349. Nonattributed peaks correspond mainly to primary minerals (i.e., feldspar). Dashed-line areas of (060) smectite peaks are shown in detail in Figure F3. A. Broad peak at 12.5-15 $\AA$ and small peak at $7 \AA$ correspond to occurrences of smectites and kaolinite, respectively. Numerous indicated peaks show that calcite is also present in this sample, and a small peak at $6.5 \AA$ likely indicates zeolites. B. Broad peak at $12.5-15 \AA$ and moderate peak at $7 \AA$ correspond to occurrences of smectites and kaolinite, respectively. Similar to the sample in $\mathrm{A}$, numerous indicated peaks correspond to calcite and a small peak at $6.5 \AA$ likely indicates zeolites.
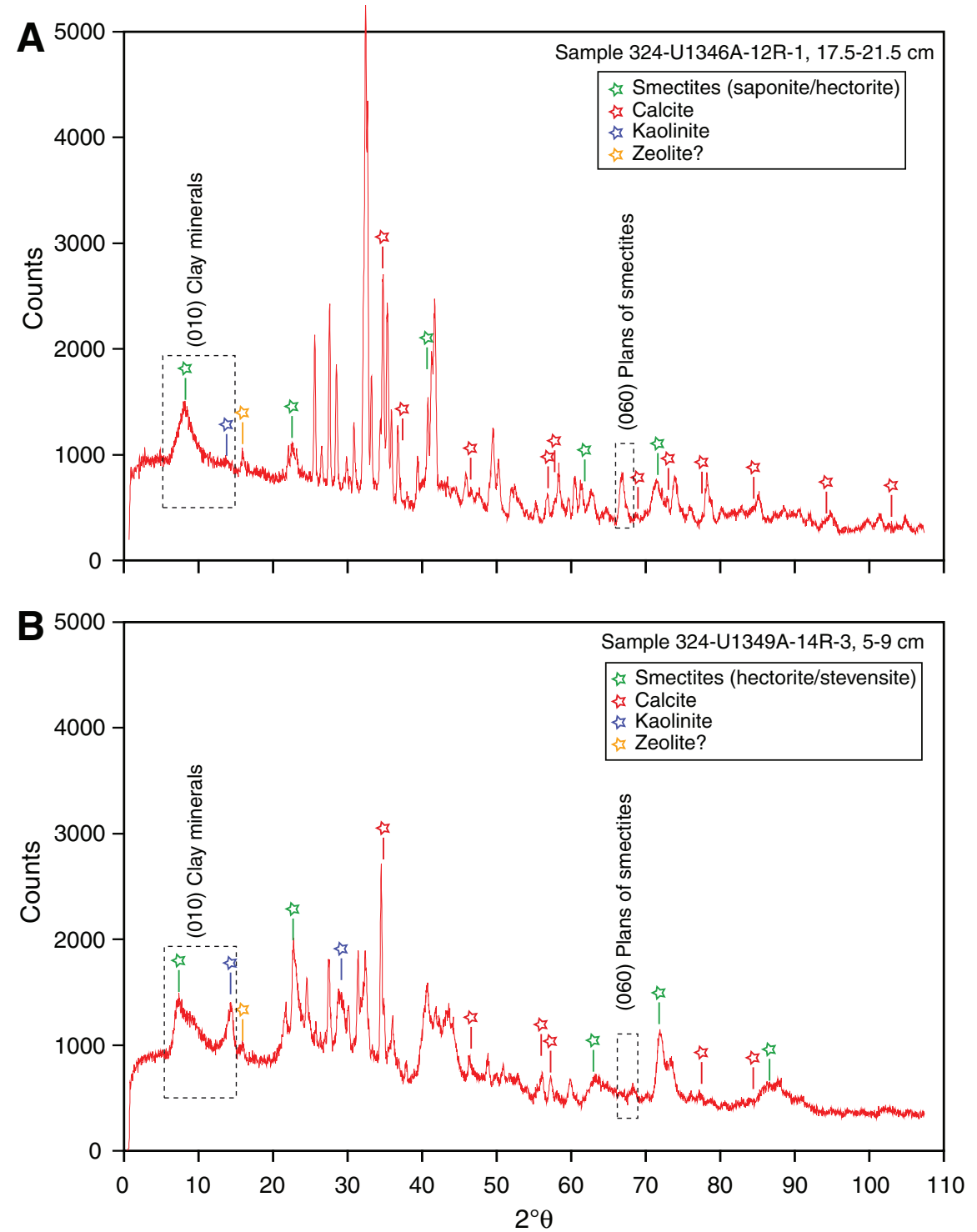
Figure F2. X-ray diffraction oriented patterns of the $<2 \mu \mathrm{m}$ fraction of two decarbonated basaltic samples, Sites $\mathrm{U} 1346$ and $\mathrm{U} 1349 . \mathrm{AD}=$ air-dried condition, $\mathrm{EG}=$ saturated with ethylene glycol, $\mathrm{H}=$ heated at $550^{\circ} \mathrm{C}$ for $2 \mathrm{~h}$. A. Peaks at 17, 15, and $10 \AA$ on the EG, AD, and H spectra, respectively, indicate smectites. The peak at $10 \AA$ on the $\mathrm{H}$ spectrum cannot indicate illite occurrence because of the lack of peaks in the AD and EG spectra. B. Peaks indicate kaolinite (peaks at $7 \AA$ on the AD and EG spectra and no peak on the H spectrum), smectites, and chlorite or an interstratified smectite-chlorite. Peaks between 14 and $15 \AA$ on the AD spectrum indicate an interstratified smectite-chlorite, whereas peaks at 14 and $10 \AA$ on the $\mathrm{H}$ spectrum indicate chlorite and smectites, respectively. Peaks at $\sim 4.8 \AA\left(18.5^{\circ} 2 \theta\right)$ are replicates.
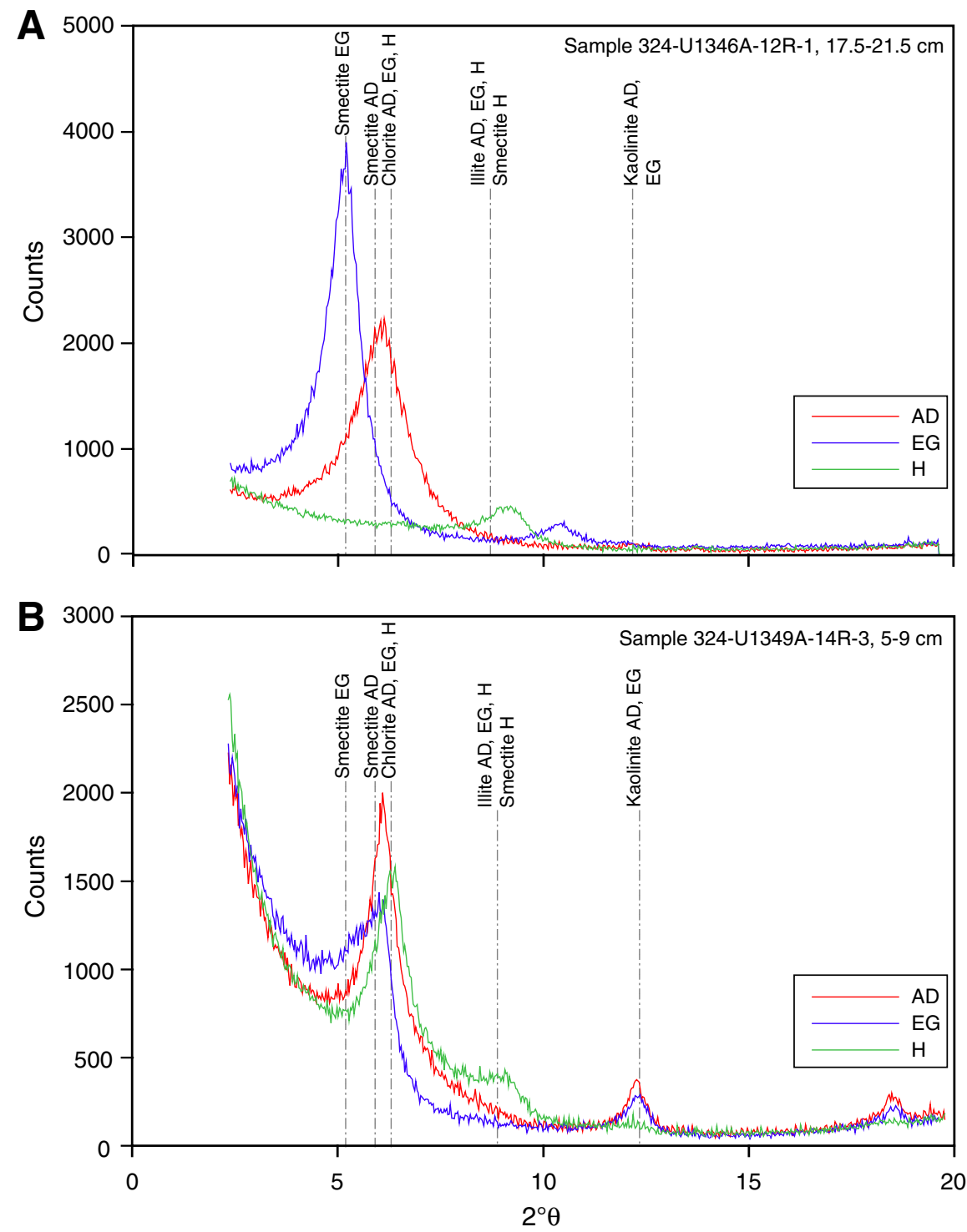
Figure F3. Detail of X-ray diffraction patterns of (060) smectite peaks in Figure F1, Sites U1346 and U1349. Peaks at $1.538,1.530,1.520,1.498$, and $1.490 \AA$ correspond to saponite, hectorite, stevensite, nontronite, and montmorillonite, respectively. A. Peaks at 1.538 and $1.490 \AA$ Andicate saponite/hectorite and montmorillonite. B. Peaks at 1.498 and between 1.520 and $1.538 \AA$ indicate nontronite and a Mg-smectite whose composition is between hectorite and stevensite.
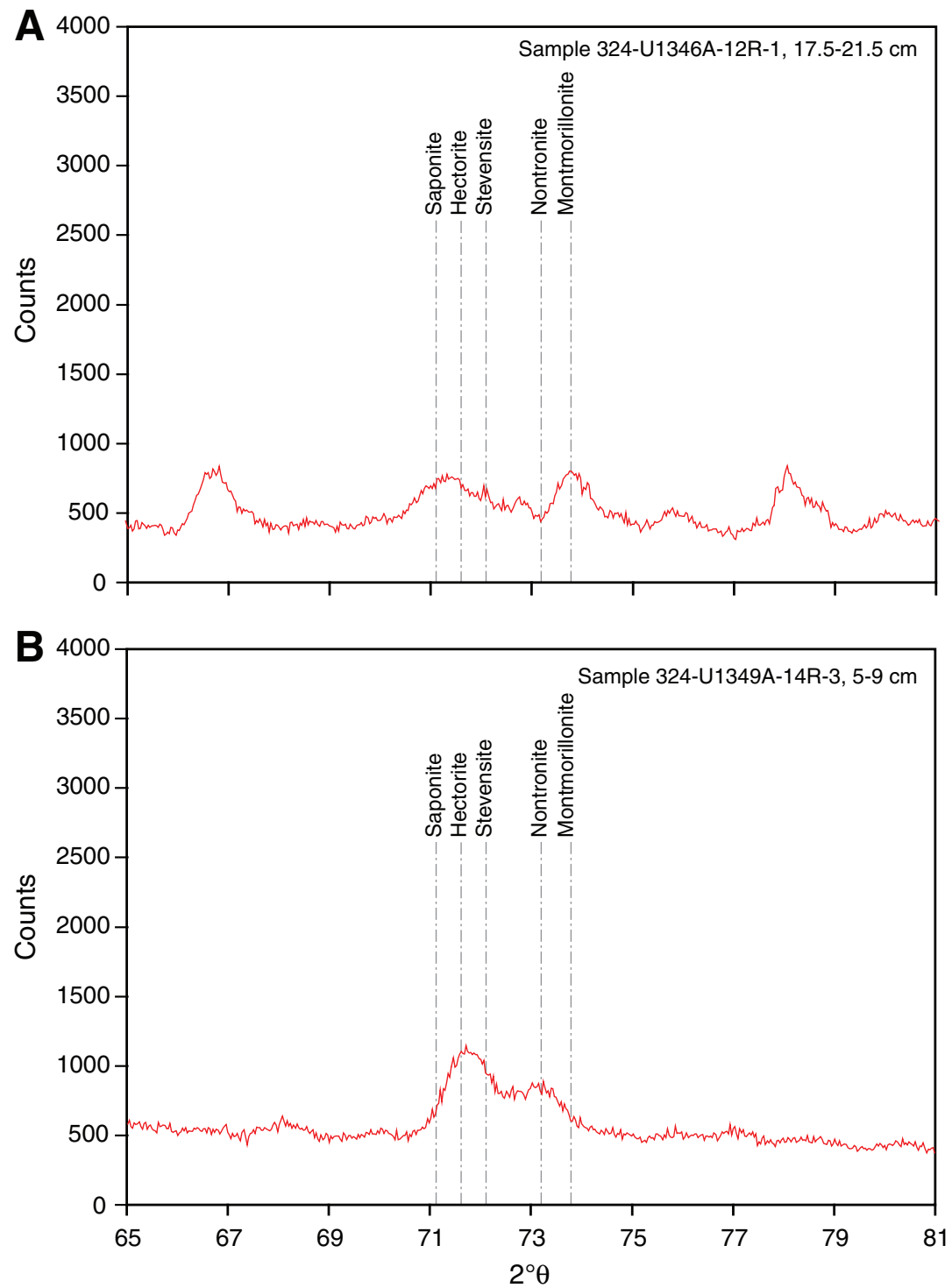
Figure F4. X-ray diffraction pattern obtained on nonoriented bulk rock powder, Hole U1346A. No peak characteristic of smectites is observed in the 12.5-15 $\AA$ area. Dashed-line area corresponds to the relative position of (010) peaks of clay minerals. Small peaks at 10 and $1.517 \AA$ indicate celadonite, and a small peak at $9 \AA$ indicates zeolite (e.g., heulandite series). Nonattributed peaks correspond mainly to primary minerals (i.e., feldspar).

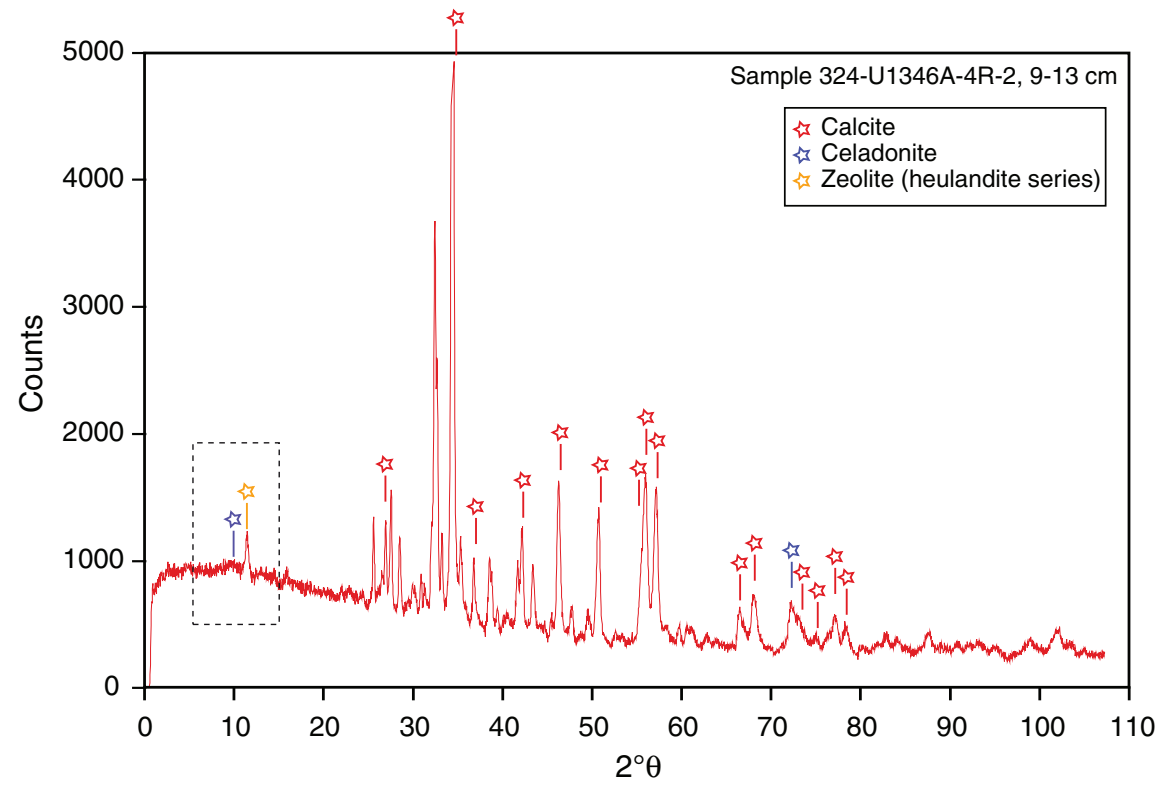


Figure F5. X-ray diffraction pattern obtained on nonoriented bulk rock powder, Hole U1349A. Pattern shows the lack of clays (usually observed in the dashed-line area) in this sample, whereas iddingsite was evidenced petrographically in thin section. Two small peaks are visible at 7 and $6.5 \AA$ that may correspond to kaolinite and zeolites. Numerous calcite peaks are indicated and nonattributed peaks correspond mainly to primary minerals (i.e., feldspar).

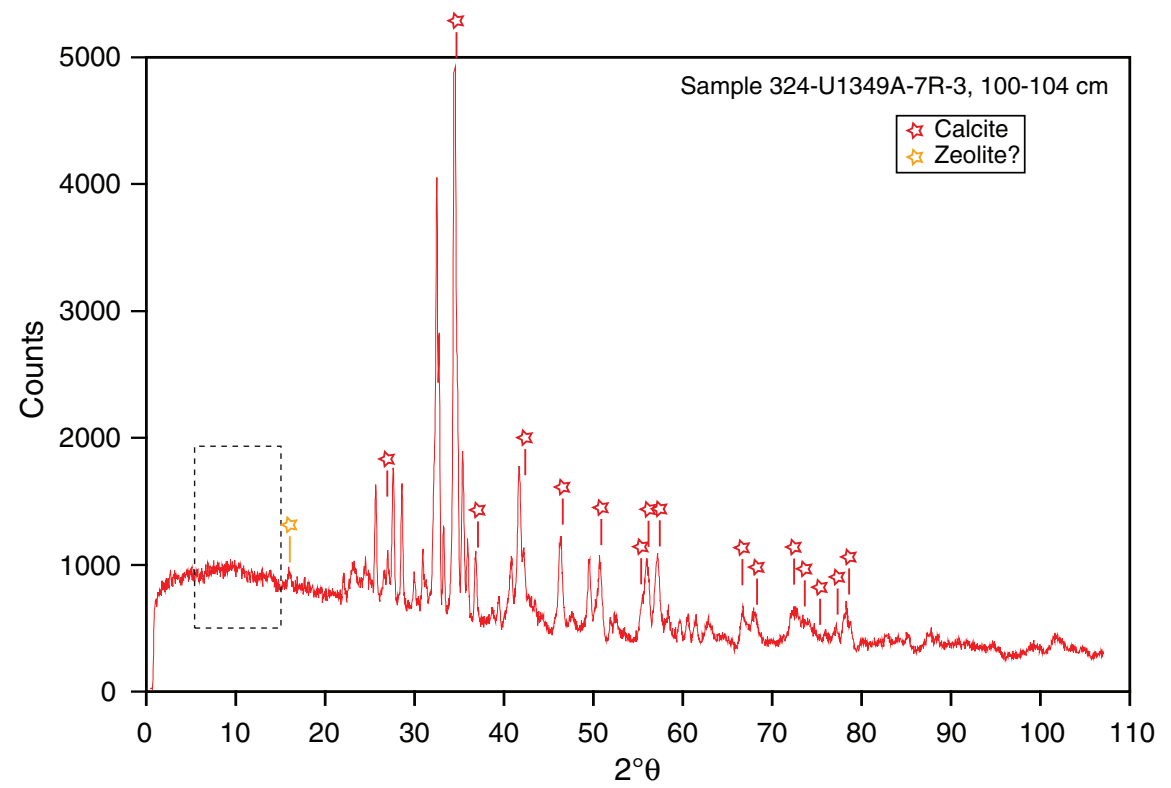




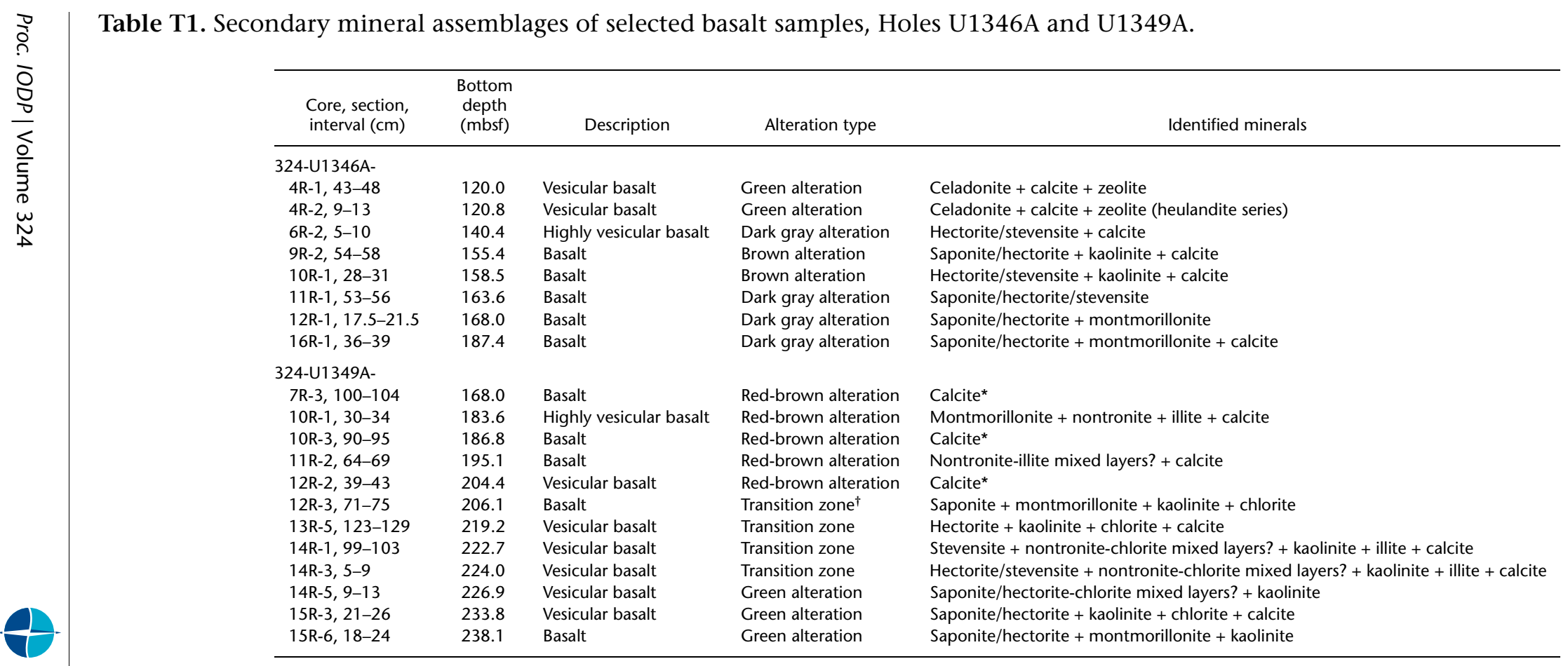

$*$ = no clay mineral could be identified either on bulk rock or oriented section XRD. $\dagger=$ sample is only slightly affected by alteration and a description of alteration better corresponds to transition zone alteration rather than red-brown alteration as initially described during IODP Expedition 324 (Expedition 324 Scientists, $2010 \mathrm{a}$ ). 